\title{
Integrated Reporting Practices in Europe and Value Relevance of Accounting Information under the Framework of IIRC
}

\author{
Salvatore Loprevite ${ }^{1}$, Daniela Rupo ${ }^{2} \&$ Bruno Ricca $^{2}$ \\ ${ }^{1}$ Department of Sciences of the Society and the Mediterranean Area Formation, University "Dante Alighieri" of \\ Reggio Calabria, Italy \\ ${ }^{2}$ Department of Economics, University of Messina, Italy \\ Correspondence: Salvatore Loprevite, Department of Sciences of the Society and the Mediterranean Area \\ Formation, University “Dante Alighieri” of Reggio Calabria, Via del Torrione, 95, 890125, Reggio Calabria (RC), \\ Italy. Tel: 39-0965-3696-299. E-mail: loprevite@unistrada.it
}

Received: December 30, 2017

Accepted: February 20, 2018

Online Published: March 30, 2018

doi:10.5539/ijbm.v13n5p1

URL: https://doi.org/10.5539/ijbm.v13n5p1

\begin{abstract}
The research has been conducted on a sample of European companies with the aim to investigate whether the adoption of the Integrated Reporting (IR) affects the value relevance of summary accounting information. The relations between Market Value (MV) and traditional accounting information (Book Value and Earnings) are studied by a linear price-level model, typical of the studies on the value relevance of accounting information. The results of analysis show that the degree of value relevance of Earnings is significantly different for companies that publish an Integrated Report compared to companies adopting traditional financial reporting. The study confirms the assessment made by IIRC and the other advocates: Integrated Reporting is expected to improve the quality of traditional accounting information for providers of financial capital.
\end{abstract}

Keywords: integrated report, value relevance, IIRC framework, accounting information, Europe

\section{Introduction}

This study is based on empirical research conducted on a sample of European companies that publish an Integrated Report under the Framework of the International Integrated Reporting Council (IIRC, 2013), with the purpose of verifying whether this publication influences the value relevance of traditional accounting information (Earning and Book Value).

The relation between the publication of an Integrated Report (IR) and the value relevance of traditional accounting information represents an important emerging research stream, considered in literature as a field that deserves to be further investigated through empirical studies (Cheng, Green, Conradie, Konishi, \& Romi, 2014; de Villiers, Rinaldi \&, Unerman, 2014; Morros, 2016; Cuozzo, Dumay, Palmaccio, \& Lombardi, 2017)

For the International $<\mathrm{IR}>$ Framework the adoption of an IR approach «aims to improve the quality of information available to providers of financial capital to enable a more efficient and productive allocation of capital». The literature interpreted this aim as an expectation of the IIRC Framework towards an increase of value relevance of accounting information by the adoption of an Integrated Reporting approach (Baboukardos \& Rimmel, 2016). Although many studies have been addressed to this topic (Schadewitz \& Niskala, 2010; Eccles \& Serafeim, 2011; Cho, Lee, \& Pfeiffer, 2013; Middleton, 2015; Baboukardos \& Rimmel, 2016), it is still unclear how the adoption of an integrated approach to reporting could impact the value relevance of financial information. In fact, some authors approach this issue as «one of the main unanswered integrated reporting questions» to address in further research (Solomon \& Maroun, 2012; Cheng et al., 2014; de Villiers et al., 2014; Morros, 2016).

Our study aims to investigate this specific research area considering the value relevance of voluntary reporting (IR) in relation to mandatory reporting (financial reporting) in the European context. The paper is an initial extent of our previous research (2017) that, to the best of our knowledge, represents the first attempt to verify the effects of the integrated reporting approach under the IRR Framework on a sample of companies covering to the whole of Europe.

The paper is structured as follows. Section 2 presents a literature review on Integrated Reporting approach, that 
focus on empirical studies about the relation between integrated information and summary accounting information. The theoretical background also considers empirical studies on the value relevance of non-financial information concerned with other voluntary reports, considered relevant for the purpose of this research. Section 3 sets out in detail the research design. Section 4 addresses the findings of the empirical analysis. Section 5 discusses the results, highlighting the limits and prospects for further research development.

\section{Literature Review}

The IIRC was created in 2010 with the support of the Accounting for Sustainability (A4S) initiative led by HRH The Prince of Wales and the Global Reporting Initiative, aiming to develop a framework for integrated reporting and to promote its use. The IIRC Framework, issued in 2013, is a principle-based document setting out seven guiding principles and eight content elements for an integrated report, whose primary aim, as declared in the preamble, is to "improve the quality of information available to providers of financial capital to enable a more efficient and productive allocation of capital" (IIRC Framework, 2013, p. 2).

The recent theoretical literature on this topic identified some issues to address in the future research agenda (Cheng et al., 2014; de Villiers et al., 2014; Morros, 2016; Cuozzo et al., 2017), concerned with the content of the integrated report, the quality of information and other relevant aspects among which the value relevance of information provided by the integrated report. This study intends to answer this last claim, investigating regard integrated reporting in the perspective of the wide theme of value relevance, to which many efforts have been devoted in the last decade, referred to various types of external reports produced by companies, on voluntary or mandatory basis.

The research on value relevance of information is not new, as it dates back to a couple of decades ago, but in recent years this interest has been moving from the field of mandatory financial information to voluntary information and integrated reporting. An increasing number of scholars, basing on the assumption that information is value relevant when it is associated with investors' valuation of the firm as reflected in the firm's stock price, have begun to investigate this issue with reference to social, environmental and integrated reporting.

This growing interest is likely fuelled by controversial results emerged in empirical researches focused on the value relevance of financial information (Barth, Beaver, \& Landsmann, 2001; Devalle, 2010). Given these controversial results, it is not possible to exclude that other factors and sources of information that the accounting system is not able to capture could influence investors' choices.

Since 1996, when Amir and Lev, questioning the value relevance of financial and non-financial information in the wireless communications industry, observed a decreasing relevance of financial information as associated with the increasing relevance of intangibles, many studies have been devoted to this field. Some of them have considered the effects of the change in accounting rules and GAAP regarding intangibles (Soderstrom \& Sun, 2007; Horton \& Serafeim, 2007; Bilal \& Abdenacer, 2016); other studies have emphasized that traditional accounting information cannot anymore satisfy the investors' needs of information, especially in presence of high value of intangibles (Lev \& Feng, 2016; Giuliani \& Marasca, 2011; Zambon, 2004; Aboody \& Lev, 1998).

Following a different perspective, some studies have investigated the value relevance of non-financial voluntary or mandatory reporting in relation to traditional accounting-based information.

For a non-comprehensive review of the literature on the subject of the paper, but with the purpose to trace the direction and the emerging results of studies conducted in this field, we hereafter draw the attention on some relevant empirical contributions, identifying the main research streams in the wide area encompassing the value relevance of financial and non-financial information.

The first search stream, probably the closest to the topic here investigated, is concerned with works about the relevance of Integrated Reporting, referring to the first context in which the adoption of the Integrated Report has become mandatory, the South Africa. Indeed, firms listed on the Johannesburg Stock Exchange must produce the IR according to the "King III Report" since 2010. The Integrated Reporting is conceived to support providers of financial capital with useful information for their capital allocation decisions. Referring to this objective of the Integrated Reporting, the empirical researches about the value relevance of IR intend to verify if what is asserted by IIRC finds confirm in practice. This path of research is aimed to examine the quality of information and the usefulness of IR, by assessing the capital market effects of its mandatory adoption (Cho et al., 2013; Eccles \& Serafeim, 2011; Middleton, 2015; Solomon \& Maroun, 2012; Baboukardos \& Rimmel, 2016; Bernardi \& Stark, 2016; Lee \& Yeo, 2016). Although they are related to a specific context, and to mandatory reporting practice, the results of these studies are considered significant because, regardless of whether the adoption of IR is voluntary or mandatory, they allow evaluating the effects of integrated reporting on investors' choices. They seem to 
support the assertion that IR improves the quality of information for providers of financial capital. There is also evidence that the mandatory introduction of integrated reporting in South Africa "has resulted in an increase in the extent of disclosure of human, social and relational, natural and intellectual capital information of the listed companies" (Setia, Abhayawansa, Joshi, \& Huynh, 2015). Examining the association between Integrated Reporting and firms' valuation for a sample of listed companies in South Africa, Lee \& Yeo (2016) found that firms' valuation is positively associated with Integrated Reporting disclosures and that firms with high Integrated Reporting outperform those with low Integrated Reporting both in terms of stock market and accounting performance. Nevertheless, the results of these studies are controversial as to the relevance of summary accounting information.

The second stream of research concerns some empirical studies which have tried to verify the value relevance of voluntary disclosure, with reference to stand-alone reports (Social, Environmental and Sustainable Reports) in different contexts, all over the world. Among these, Cormier \& Magnan (2007), investigating on environmental reporting in Germany, France and Canada, found controversial results in different countries: the decisions to report environmental information have shown a moderating impact on the stock market valuation in the Germany firms earnings, whilst it does not significantly influence the stock market valuation of Canadian and French firms earnings. Previously, Hassel, Nilsson, \& Nyquist (2005) had investigated the value relevance of environmental performance using Swedish data, finding that environmental performance (measured by an environmental index) has a negative influence on the market value of firms. This effect has been explained as a consequence of the fact that high environmental performance is costly, thus having a negative impact on expected earnings and market values.

With regard to social reporting, Qiu, Shaukat and Tharyan (2014) found that firms characterized by a higher social disclosure have higher market values, too. Other studies lead to opposite results: the results of a research by Carnevale \& Mazzuca (2014), which applied value-relevance analysis to the social reporting variable on European listed banks, do not show a significant correlation between the publication of a social report and the stock price, though with differences in the countries investigated: in some countries, the social report is seen as value relevant and positively affects the stock price; in other countries, the social report remains value relevant but negatively affects the stock price.

The study by Schadewitz \& Niskala (2010), which explored through the Ohlson model the responsibility reporting of Finland listed companies according to the Global Reporting Initiative (GRI), found evidence to the idea that responsibility reporting is an important explanatory factor for a firm's performance and market value. Similarly, Kaspereit \& Lopatta (2016) developed a value relevance study for the 600 largest European companies with the Feltham and Ohlson valuation model as a reference point. The results indicate a positive association between corporate sustainability and market effects in the period under observation (2002-2011).

The third stream of research is about the voluntary narrative sections of company annual reports, aimed to explore questions of usefulness and materiality of annual report narrative disclosures. These studies have widely examined the discretionary disclosures made by firms to analyse their impact on decision makers and on investment analysts' stock recommendations (Vafaei, Taylor, \& Ahmed, 2011).

\section{Research Design}

\subsection{Research Questions}

We aim to verify whether the traditional accounting information of "IR Reporters" has a different value relevance compared to "Non-IR Reporters". Our empirical analysis thus has to answer the following research questions:

R.Q.1 -Within the European Union, does the value relevance of traditional accounting information (Book Value and Earnings) provided by "IR Reporters" differ significantly from that of "Non-IR reporters"?

R.Q.2 -Is the summary accounting information of "IR reporters" more value relevant?

We know that a positive answer to the two research questions does not necessarily mean that the IR approach is the only reason explaining the different usefulness of financial reporting for investors, that is to say, the value relevance of accounting information, for at least two reasons.

First, unlike other similar analysis conducted in this field (Baboukardos \& Rimmel, 2016), our sample does not refer to the same companies observed in a longitudinal temporal perspective (two different periods, pre- and post- mandatory adoption of an IR approach). For this reason, if we find differences between our two groups of companies regarding the value relevance of accounting information, they could be due, in part, to the different reality of the companies and not to a better quality of traditional accounting information, as an effect of IR 
adoption. From this point of view, we also recognize doubts about potential selection bias highlighted in previous studies examining voluntary reporting (Barth, Cahan, Chen, \& Venter, 2017) and difficulties of extending the results of research conducted on companies voluntarily adopting particular reporting practices to all firms (Pope \& McLeay, 2011)

Second, we agree that there are other primary information sources for investors, and a low timeliness of voluntary reporting, which bring into question the usefulness of Integrated Reporting (Dumay \& Tull, 2007).

It he analysis should find statistically significant difference between our two sub-samples, we believe this could be an important element that supports improved knowledge and understanding of the potential effects expected from the adoption of an integrated reporting approach on the value relevance of summary accounting information; in particular, if findings regarding the different degree of value relevance of accounting information are consistent with those obtained in previous studies in different contexts (mandatory, non-mandatory) and countries.

We will be come back to this matter in section 5, after the presentation of the linear price-level model used for data processing.

\subsection{Sample}

For our researchwe use two groups of European listed companies:

1. Companies which publish the integrated report (hereafter, "IR Reporters") under the IIRC framework;

2. Companies which do not present the integrated report under the IIRC framework (hereafter, "Non-IR Reporters"). This group is composed of an equal number of firms, selected among listed companies considered to be comparable to "IR Reporters" because they operate in the same sector and in the same country. In this way, we have a "balanced" sample (1:1 ratio) of "IR Reporters" and "Non-IR Reporters" for each country.

On its website, the International Integrated Reporting Council (IIRC) presents a list of "IR reporters", defined as «those organizations whose reports refer to the IIRC or the International $<\mathrm{IR}>$ Framework, or are influenced by the Framework through participation in $<\mathrm{IR}>$ Networks». Selecting by region "Europe", there is a list of 171 companies, on which we conducted the first selection process described in table 1.

Table 1. Step 1 of sample selection (IR Reporters)

\begin{tabular}{ll}
\hline & Numbers of items \\
\hline$<$ IR Reporters list $>$ & 171 \\
Duplicate firms & -1 \\
Firms from non-EU companies & -26 \\
Non-profit organizations & -10 \\
Non-listed companies & -25 \\
Other cases & -9 \\
Final number form step 1 & 100 \\
\hline
\end{tabular}

Companies listed after 2014 and companies with a financial year that does not coincide with the calendar year were removed. Furthermore, we excluded companies for which we could not find a complete set of market data and/or accounting data. Table 2 summarizes the process.

Table 2. Step 2 of sample selection (IR Reporters)

\begin{tabular}{ll}
\hline & Number \\
\hline Final number from step 1 & 100 \\
Listed after 2014 & -1 \\
Financial Year $\neq$ Calendar Year & -11 \\
Unavailable market data and/or accounting data & -34 \\
Final number form step 1 & 54 \\
\hline
\end{tabular}

For "Non-IR Reporters", we examined companies operating in the same sector (and sub-sector) as "IR Reporters" for each country, randomly choosing items, until we found companies that could be suitable for analysis because they did not adopt IR and had a financial year coinciding with the calendar year. Once more, in order to verify 
that these companies were not influenced by the IRRC Framework, reports were first coded by the lead author, then checked for consistency by the second author and any discrepancies were discussed in order to agree the final classification of data. In this final process, it was not possible to find a match for 10 "IR reporters".

The result of this process is a "balanced" sample of 88 firms chosen for the two years (2014 and 2015) under examination (i.e. 176 firm/year observations) (table 3).

Table 3. Step 3 of sample selection (IR Reporters and Non-IR Reporters)

\begin{tabular}{llll}
\hline & $\begin{array}{l}\text { Number } \\
\text { Reporters }\end{array}$ & $\begin{array}{l}\text { IR } \\
\text { Number } \\
\text { Non-IR } \\
\text { Reporters }\end{array}$ & Total \\
\hline Final number from step 2 & 54 & & \\
Comparable firms & & 44 & \\
Missing comparable firms & -10 & & 88 \\
Final balanced sample (Number of firms) & 44 & 44 & 176 \\
Firm/Year observations & 88 & 88 & \\
\hline
\end{tabular}

\subsection{Data}

The linear price-level model here used (see section 4) associates the firm's market value of equity (MV) with its book value (BV) and earnings (E). The accounting data (Book Value - BV; Earnings - E) were collected directly from the annual report published by the companies. The market data (MV) was sourced from monthly market reports published by the Stock Exchanges. Book Value (BV) and Earnings (E) refer to the end of the financial year (i.e., 31/12/2014 and 31/12/2015); market capitalization refers to the date of 30 June of year $n+1$ (i.e., 30 June 2015 and 30 June 2016). This date is frequently used in value relevance studies belonging to the category of association studies(Kothari, 2001; Mechelli, 2013).For these three basic variables, the scale effect (Easton \& Sommers,2003; Barth \& Clinch, 2009) was mitigated by dividing each variable by the value of "Total assets".On this point, we must mention that, in the literature about the value relevance of accounting information, many deflators have been used to mitigate the scale effect, without resolving the issue completely(Mechelli, 2013).Number of common shares is the most frequently used. However, we observe that the number of common shares - on equal share capital - is inversely proportional to the nominal value. For this reason, the use of this deflator could have potential distortive effects (Loprevite \& Ricca, 2016). Conversely, in our opinion "Total assets" better expresses the size of companies.

\section{Data Processing}

For data processing a simple additive model was initially tested:

$$
M V=\beta_{0}+\beta_{1} E+\beta_{2} B V+\beta_{3} i r_{-} \text {rep }
$$

The dummy variable "ir_rep" allows us to distinguish between firms that publish an integrated report $($ ir_rep $=1)$ and those that do not (ir_rep $=0$ ) and the effect of $E$ and $B V$ is always equal to $\beta_{1}$ and $\beta_{2}$. In this case, the low value of $\mathrm{R}^{2}(0.18)$ and the non-significance of $\beta_{3}$ (Table 3 ) lead us to conclude that this model does not exploit all the information contained in the regressors.

Table 1. Result of regression ( $\mathrm{MV}=\beta_{0}+\beta_{1} \mathrm{E}+\beta_{2} \mathrm{BV}+\beta_{3}$ ir_rep)

\begin{tabular}{llllllll}
\hline & Value & $\begin{array}{l}\text { Standard } \\
\text { error }\end{array}$ & $\mathrm{T}$ & $\mathrm{Pr}>|\mathrm{t}|$ & $\mathrm{F}$ & $\operatorname{Pr}>\mathrm{F}$ & $\mathrm{R}^{2}$ \\
\hline Intercept & -0.0041 & 0.2094 & -0.0194 & 0.9845 & 13.3269 & $<0.0001$ & 0.1886 \\
E & 0.8305 & 0.3566 & 2,3285 & 0.0210 & & & \\
BV & 2,0101 & 0.3396 & 5,9195 & $<0.0001$ & & & \\
Ir_rep-1 & 0.2898 & 0.1918 & 1,5111 & 0.1326 & & \\
Ir_rep-0 & 0.0000 & 0.0000 & & & & & \\
\hline
\end{tabular}

In accordance with Baboukardos and Rimmel (2016), we decided to verify whether forms of interaction exist among the variables under consideration. Among the models devised that include all the possible variants of 
interactions among the variables, we exclude, for sake of brevity, all those which show a low value for $\mathrm{R}^{2}$, problems of parameter significance and suspected multicollinearity, restricting ourselves to the following models:

$$
\begin{gathered}
M V=\beta_{0}+\beta_{1} E+\beta_{2} B V+\beta_{3} i r_{-} r e p+\beta_{4}\left(E^{*} i r_{-} r e p\right)+\beta_{5}\left(B V^{*} i r_{-} r e p\right) \\
M V=\beta_{0}+\beta_{1} E+\beta_{2} B V+\beta_{3} i r_{-} r e p+\beta_{4}\left(E^{*} i r_{-} r e p\right) \\
M V=\beta_{0}+\beta_{1} E+\beta_{2} B V+\beta_{3} i r_{-} r e p+\beta_{4}\left(E^{*} i r_{-} r e p\right)+\beta_{6}\left(E^{*} B V\right)
\end{gathered}
$$

\begin{tabular}{|c|c|c|c|c|c|c|c|c|c|}
\hline Model & & Value & $\begin{array}{l}\text { Standard } \\
\text { error }\end{array}$ & $\mathrm{t}$ & $\operatorname{Pr}>|t|$ & $\mathrm{F}$ & $\operatorname{Pr}>F$ & $\begin{array}{l}\mathrm{R}^{2} \\
\text { corrected }\end{array}$ & VIF \\
\hline \multirow{9}{*}{1} & Intercept & 0.2595 & 0.2019 & 1.2852 & 0.2005 & 30.0925 & $<0.0001$ & 0.4539 & \\
\hline & E & 0.2225 & 0.2973 & 0.7484 & 0.4552 & & & & \\
\hline & BV & 1.4968 & 0.3580 & 4.1811 & $<0.0001$ & & & & \\
\hline & ir_rep-1 & -0.4137 & 0.2832 & -1.4609 & 0.1459 & & & & 3.3881 \\
\hline & ir_rep-0 & 0.0000 & 0.0000 & & & & & & \\
\hline & E*ir_rep-1 & 13.6194 & 1.4691 & 9.2704 & $<0.0001$ & & & & 1.2508 \\
\hline & E*ir_rep-0 & 0.0000 & 0.0000 & & & & & & \\
\hline & BV*ir_rep-1 & 0.2741 & 0.5729 & 0.4784 & 0.6330 & & & & 3.7148 \\
\hline & BV*ir_rep-0 & 0.0000 & 0.0000 & & & & & & \\
\hline \multirow{7}{*}{2} & Intercept & 0.2088 & 0.1714 & 1.2179 & 0.2249 & 37.7285 & $<0.0001$ & 0.4564 & \\
\hline & E & 0.2295 & 0.2962 & 0.7748 & 0.4395 & & & & \\
\hline & BV & 1.6039 & 0.2789 & 5.7517 & $<0.0001$ & & & & 1.0540 \\
\hline & ir-1 & -0.3047 & 0.1678 & -1.8161 & 0.0711 & & & & 1.1946 \\
\hline & ir-N & 0.0000 & 0.0000 & & & & & & \\
\hline & E*ir-1 & 13.7342 & 1.4461 & 9.4973 & $<0.0001$ & & & & 1.2174 \\
\hline & E*ir-N & 0.0000 & 0.0000 & & & & & & \\
\hline \multirow{8}{*}{3} & Intercept & 0.2172 & 0.1702 & 1.2765 & 0.2035 & 31.3821 & $<0.0001$ & 0.4647 & \\
\hline & E & -0.3027 & 0.4049 & -0.7475 & 0.4558 & & & & \\
\hline & BV & 1.5750 & 0.2771 & 5.6834 & $<0.0001$ & & & & 1.0571 \\
\hline & ir-1 & -0.2928 & 0.1666 & -1.7578 & 0.0806 & & & & 1.1963 \\
\hline & ir-N & 0.0000 & 0.0000 & & & & & & \\
\hline & $\mathrm{E} * \mathrm{BV}$ & 3.1023 & 1.6229 & 1.9116 & 0.0576 & & & & 2.3537 \\
\hline & E*ir-1 & 12.5283 & 1.5676 & 7.9922 & $<0.0001$ & & & & 1.4527 \\
\hline & E*ir-N & 0.0000 & 0.0000 & & & & & & \\
\hline
\end{tabular}

Processing produces the values shown below in table 5

Table 5. Result of regressions

Making the general assumption that verification of the significance of the intercept is not of importance for analysis purposes, as it does not affect the goodness of fit, no reference will be made to it in this study.

Thus, observing the results (Table 5), it can be seen that:

a) The first model can be excluded since it shows the worst fit $\left(\mathrm{R}_{\text {corr }}^{2}=0.45\right)$ and VIF values that lead us to believe that there may be collinearity. (Note 1) Moreover, the interaction term (BV*ir_rep) is not significant, indeed it is not possible to refute the hypothesis $\mathrm{H}_{0}: \beta_{5}=0$ against the hypothesis $\mathrm{H}_{1}: \overline{\beta_{5}} \neq 0$, since the value of statistic $\mathrm{t}$ corresponding to the interaction ( $\mathrm{BV} * \mathrm{ir} \_$rep) is 0.47 and thus the $\mathrm{p}$-value $=0.633>0.05$.

b) The second model is preferred to the third respecting the hierarchy principle and the principle of parsimony, considering that the amount of variance of the dependent variable (MV) expressed by the second and third regressions is almost identical and that the VIF of the variable ( $\left.\mathrm{E}^{*} \mathrm{BV}\right)$ is high and could therefore indicate the presence of multicollinearity of this variable with the others. (Note 2) 
Thus, the equation that best represents the phenomenon under study is:

$$
M V=0.20+0.22 *(E)+1.60 *(B V)-0.30 * \text { (ir_rep })+13.73 *\left(E^{*} \text { ir_rep }\right)
$$

The model 2 (Table5) is acceptable within the parameters $(\mathrm{F}=37.72 ; \mathrm{Pr}>\mathrm{F}<0.0001)$.

Moreover, it is important to underline that the goodness of the model with interactions with respect to the model without interactions is confirmed, with a significance level of $5 \%$, by test $F\left(F_{3,4}=90.19\right.$; p_value $=0.0003<$ 0.05 ) allowing us to compare the sum of the squares of the regression for the model containing interactions with the corresponding sum for the model without interactions. (Note 3). Since, as mentioned above, ir_rep is a dummy variable, the model chosen (2) can be rewritten thus:

\begin{tabular}{ll}
\hline ir_rep & Equation \\
\hline$=0$ (firms that do not present an integrated report) & $\mathrm{MV}=0.20+0.22 *(\mathrm{E})+1.60 *(\mathrm{BV})$ \\
$=1$ (firms that present an integrated report) & $\mathrm{MV}=-0.1+13.95 *(\mathrm{E})+1.60 *(\mathrm{BV})$ \\
\hline
\end{tabular}

\section{Findings}

The linear price-level model, typically used in studies on the value relevance of accounting information, has been developed on the basis of the original Ohlson model (Ohlson, 1995), which considers accounting information value relevant if it has a significant statistical relation with the market value of companies (Barth et al., 2001; Kothari, 2001; Mechelli, 2013).We developed (see section 4), different linear price-level models by pooling observations for the two years under examination (2014 and 2015) and introducing a dummy variable "ir_rep" to distinguish companies that publish an Integrated Report (ir_rep =1) from those which do not present one (ir_rep=0). In particular, to establish whether there is a consistent difference in valuation of BV and $\mathrm{E}$ between the two groups of companies, we used interaction models that include all possible variants of interactions between available variables. This approach is similar other papers that test the value relevance of Integrated Reports or other forms of voluntary non-financial reporting (Berthelot, Coulmont, \& Serret, 2012; Carnevale \& Mazzuca, 2014; Lourenco, Callen, Branco, \& Curto, 2014; Baboukardos \& Rimmel, 2016).

In general terms, we point out that the model could determine whether a systematic difference in the valuation of Earnings (E) and Book Value (BV) by investors exists for the two groups of companies, essentially by the interaction between the coefficients $\beta$ for these independent variables and ir_rep (dummy variable). In particular, if these two coefficients are significantly different from zero, it means that there is a different value relevance of Earning and Book Value for the groups of companies. In the opposite case (the two coefficients are not significantly different from zero), the difference does not exist.

As we have seen, however, in the models that we have tested the interaction term (BV*ir_rep) is not significant (see section 4), therefore it is not possible to explain the differences in the value relevance of BV between two groups of companies. Instead, we can examine the value relevance of Earning using the model number 2 to present the results

$$
M V=\beta_{0}+\beta_{1} E+\beta_{2} B V+\beta_{3} i r_{-} r e p+\beta_{4}\left(E * i r_{-} \text {rep }\right)
$$

The result obtained for the equation is the following

$$
M V=0.20+0.22 *(E)+1.60 *(B V)-0.30 *\left(\text { ir_rep }_{-}\right)+13.73 *\left(E^{*} \text { ir_rep }\right)
$$

It can be rewritten as 2.a.1 for "IR Reporters" and as 2.a.2 for "Non-IR Reporters"

$$
\begin{aligned}
& M V=0.20+0.22 *(E)+1.60 *(B V) \\
& M V=-0.1+13,95 *(E)+1.60 *(B V)
\end{aligned}
$$

Thus, important differences exist between the regression coefficients of Earnings.

For R.Q.1 the results of the analysis confirm that, in the European Union, there is a significantly different degree of value relevance of Earnings among "IR reporters" and "Non-IR reporters". It is not possible confirm the R.Q.1 with reference to Book Value.

Regarding R.Q.2, we can say that, for our sample and the period under investigation, the empirical evidence proves that Earnings positively and significantly (13.96) influenced investors' choices and the Market Value of "IR Reporters". On the contrary, for "Non-IR Reporters", Earnings do not have relevance for investors' choices 
$\left(\beta_{I}=0,22\right)$.

As we have already said in section 3.3 it is not possible to declare with certainty that the cause of such result is the presence of an Integrated Report. However, we now feel it is important to highlight that our empirical evidence is in line with the results obtained by recent studies (Baboukardos \& Rimmel, 2016). In particular, for the firms listed on the JSE, these authors found that the value relevance of earnings is significantly increased after the mandatory adoption of an IR approach under King III. This consistency of findings seems to confirm that the adoption of an IR approach improves the usefulness of Earnings, inducing investors to rely on it in positive terms. Even if we want to exclude a role played by Integrated Report, we should nevertheless note that a difference exists between the two groups and that it has to be explained. You may not need to wonder whether companies voluntarily publish an Integrated Report because they have positive aspects of their operations to show, but merely observe that these companies have a greater orientation towards the integrated reporting approach because they acknowledge its capacity to create value. Indeed, we can agree with those who have said that "managers who voluntarily disclose information effectively reveal that the benefits of the disclosure exceed the cost" (Barth et al., 2017). Furthermore, one might say that the adoption of Integrated Reporting improves the effectiveness of internal control systems; therefore, it fulfils the purpose of creating value within the organization, which, for some scholars, is the main purpose for developing IC (Dumay, 2016). This would be in line with the International $<\mathrm{IR}>$ Framework, which states that «integrated thinking leads to integrated decision-making and actions that consider the creation of value over the short, medium and long term».

In the light of the similarity of our results to those of many other studies, we believe that it is possible to affirm that all these factors play a role. There is a role played by integrated reporting in improving the possibilities of investors decoding traditional accounting information (Earnings); but the integrated reporting approach also plays a role within companies, because they have a better vision of the value created by Integrated Reporting inside and outside the firm. The hardest aspect is identifying the effects of the various phenomena.

\section{Discussion and Conclusion}

While the EU and the member States' legislators are working and interacting each other on the issue of non-financial information, the number of companies voluntarily adopting integrated reporting is growing steadily all over Europe and the IIRC Framework is extending its influence in this field.

Meanwhile, scientific debate is enriching with contributions aimed to define a comprehensive conceptual framework on this topic, which is still presenting controversial and complex research issues.

Our study moves in this research field with the aim to contribute to understanding the relation between the publication of an Integrated Report (IR) and the value relevance of summary accounting information. More specifically, it concerns the topic referred to the usefulness of IR to investors.

The prevailing view in literature is that the adoption of IR approach improves the quality of information available to investors and, therefore, the value relevance of accounting information (Cho et al., 2013; Middleton, 2015; Baboukardos \& Rimmel, 2016; Lee \& Yeo, 2016). Even the IIRC Framework seems willing to attribute this function to the integrated reporting (IIRC, 2013).

Our analysis provides evidence regarding a significant different degree of value relevance of Earnings between "IR reporters" and "Non-IR reporters" in the period under examination. In fact, the value relevance of Earning is higher for "Non-IR Reporters" because the regression coefficients of these companies have a significant greater absolute value (Barth et al., 2001; Mechelli, 2013) The relation between Book Value and Market Value is positive for both groups (IR Reporters and Non-IR Reporters), but were not able to examine the differences in the value relevance of $\mathrm{BV}$ between the two groups of companies because the interaction term $\mathrm{BV}^{*}$ ir_rep is not significant.

Since the cost of equity can be inferred by the relation between a firm's earnings and its market value (Kothari \& Zimmerman, 1995), looking at the value relevance of Earning we can explain the different regression coefficient (higher for "IR Reporters") in terms of negative impact on the firm's cost of equity capital, as already interpreted by others scholars (Cormier \& Magnan, 2007; Dhaliwal, Li, Tsang, \& Yang, 2014; Baboukardos \& Rimmel, 2016). More generally, looking at the use of accounting information by investors, we can say that the presence of the integrated reporting led the investors to rely on Earnings in positive terms. In both perspectives, it is possible to point out that the Integrated Reporting Approach improved the quality (in terms of usefulness and relevance) of the accounting earning.

Admittedly, it is very difficult to evaluate the effects of integrated reporting on value relevance of accounting information or, to use the words of de Villiers et al., «to determine whether the financial markets react or reflect a 
value premium in any way» (de Villiers et al., 2014, p. 20), since other variables could affect the same result. As highlighted in this paper, the theme is even more complex for studies conducted on companies that voluntarily adopt special reporting practices.

Furthermore, we are aware that the design of our study, having combined data of companies publishing an Integrated Report with others, referred to non-adopting integrated reporting practices, presents some uncertainties. In fact, the results could somehow be influenced by contextual variables, related to specific factors that characterize the reality of companies, not being an exclusive effect of IR adoption. However, this is why we preferred this model, given that a comparison between different orientations to reporting, based on a synchronous approach could prevent potential distortions that occur when we observe the same companies at different times (cyclical phenomena).

The study adds value to research on this topic, indirectly estimating the relevance of integrated reporting in the European context. As said before, the results of our analysis show that the adoption of the IR approach seems to significantly improve the quality of accounting earning, increasing the chances of investors to interpret them. At the same time, we believe that it is very likely that "Reporter IR" companies have a greater orientation towards the integrated reporting approach because they recognize its contribution to creating value.

\section{References}

Aboody, D., \& Lev, B. (1998). The value relevance of intangibles: the case of software capitalization. Journal of Accounting Research, 36(3), 161-191.

Ahmed, K., \& Falk, H. (2006). The value relevance of management's research and development reporting choice: Evidence from Australia. Journal of Accounting and Public Policy, 25(3), 231-264. https://doi.org/10.1016/j.jaccpubpol.2006.03.002

Amir, E., \& Lev, B. (1996). Value-relevance of nonfinancial information: The wireless communications industry. Journal of Accounting and Economics, 22(1-3), 3-30.

Baboukardos, D., \& Rimmel, G. (2016). Value relevance of accounting information under an integrated reporting approach: A research note. Journal of Accounting and Public Policy, 35, 437-452. https://dx.doi.org/10.1016/j.jaccpubpol.2016.04.004

Barth, M. E., \& Clinch G. (2009).Scale Effects in Capital Markets-Based Accounting Research. Journal of Business Finance \& Accounting, 36(3-4), 253-288. https://dx.doi.org/10.1111/j.1468-5957.2009.02 133.x

Barth, M. E., Beaver, W. H., \& Landsman, W. R. (2001). The Relevance of the Value Relevance Literature for Financial Accounts Standard Setter: Another View. Journal of Accounting and Economics, 31, 77-104

Barth, M. E., Cahan, S. F., Chen, L., \& Venter, E. R (2017). The Economic Consequences Associated with Integrated Report Quality: Capital Market and Real Effects. Working Papers (Faculty) - Stanford Graduate School of Business. Retrieved from https://www.gsb.stanford.edu/gsb-cmis/gsb-cmis-download-auth/435571

Bernardi, C., \& Stark, A. W. (2016). Environmental, social and governance disclosure, integrated reporting, and the accuracy of analyst forecasts. The British Accounting Review. https://dx.doi.org/10.1016/j.bar.2016.10.001

Berthelot, S., Coulmont, M., \& Serret, V. (2012). Do investors value sustainability reports? A Canadian study. Corporate Social Responsibility and Environmental Management, 19(6), 355-363. https://dx.doi.org/10.1002/csr.285

Bilal, K., \& Abdenacer, R. (2016). Intangibles and Value Relevance of Accounting Information: Evidence from UK Companies. Jordan Journal of Business Administration, 12(2), 437-458.

Carnevale, C., \& Mazzuca, M. (2014). Sustainability report and bank valuation: evidence from European stock markets. Business Ethics: A European Review, 23(1), 69-90. https://dx.doi.org/10.1111/beer.12038

Cheng, M., Green, W., Conradie, P., Konishi, N., \& Romi, A. (2014). The international integrated reporting framework: key issues and future research opportunities. Journal of International Financial Management and Accounting, 25(1), 90-119. https://dx.doi.org/10.1111/jifm.12015

Cho, S. Y., Lee, C., \& Pfeiffer, R. J. (2013). Corporate social responsibility performance and information asymmetry. Journal of Accounting and Public Policy, 32(1), 71-83. https://doi.org/10.1016/j.jaccpubpol.2012.10.005

Collins, D. W., Maydew, E. L., \& Weiss, I. S. (1997). Changes in the Value-Relevance of Earnings and Book 
Values over the Past Forty Years. Journal of Accounting \& Economics, 24(1), 39-67. https://doi.org/10.1016/S0165-4101(97)00015-3

Cormier, D., \& Magnan, M. (2007). The revisited contribution of environmental reporting to investors' valuation of a firm's earnings: an international perspective. Ecological Economics, 62(3), 613-626. https://doi.org/10.1016/j.ecolecon.2006.07.030

Cuozzo, B., Dumay, J., Palmaccio, M., \& Lombardi, R. (2017). Intellectual capital disclosure: A structured literature review. Journal of Intellectual Capital, 18(1), 9-28. https://doi.org/10.1108/JIC-10-2016-0104

de Villiers, C., Rinaldi, L., \& Unerman, J. (2014). Integrated reporting: insights, gaps and an agenda for future research. Accounting, Auditing \& Accountability Journal, 27(7), 1042-1067. https://doi.org/10.1108/AAAJ-06-2014-1736

Devalle, A. (2010). Misurazione della performance nel bilancio IFRS: comprehensive income, dibattito internazionale e value relevance. Milan: Pearson Prentice Hall.

Dhaliwal, D., Li, O.Z., Tsang, A., \& Yang, Y.G. (2014). Corporate social responsibility disclosure and the cost of equity capital: the roles of stakeholder orientation and financial transparency. Journal Accounting Public Policy, 33(4), 328-355. https://doi.org/10.1016/j.jaccpubpol.2014.04.006

Dumay, J. C. (2016). A critical reflection on the future of intellectual capital: from reporting to disclosure. Journal of Intellectual Capital, 17(1), 168-184. https://doi.org/10.1108/JIC-08-2015-0072

Dumay, J., \& Tull, A. (2007). Intellectual capital disclosure and price-sensitive Australian Stock Exchange announcements. Journal of Intellectual $\quad$ Capital, $\quad 8(2), \quad 236-255$. https://doi.org/10.1108/14691930710742826

Easton, P. D. \& Sommers, G. A. (2003). Scale and the Scale Effect in Market-Based Accounting Research. Journal of Business Finance \& Accounting, 30(1-2), 25-56. https://dx.doi.org/10.1111/1468-5957.00482

Eccles, R.G., \& Serafeim, G. (2011). Accelerating the adoption of integrated reporting. In F. De Leo, \&M. Vollbracht, (Eds.), CSR Index (pp. 70-92). InnoVatio Publishing Ltd. Retrieved from https://papers.ssrn.com/sol3/papers.cfm?abstract_id=1910965

Giuliani, M., \& Marasca, S. (2011). Construction and valuation of intellectual capital: A case study, Journal of Intellectual Capital, 12(3), 377-391. https://doi.org/10.1108/14691931111154698

Hassel, L., Nilsson, H., \& Nyquist, S. (2005). The value relevance of environmental performance. European Accounting Review, 14(1), 41-61. https://doi.org/10.1080/0963818042000279722

Horton, J., \& Serafeim, I. (2007). Does mandatory IFRS adoption improve the information environment? Working Paper, London School of Economics and Harvard Business School. Retrieved from http://papers.ssrn.com/sol3/papers.cfm?abstract_id=1264101

International Integrated Reporting Council-IIRC. (2013). The International $<I R>$ framework. Retrieved from http://integratedreporting.org/resource/international-ir-framework

Kaspereit, T., \& Lopatta, K. (2016). The value relevance of SAM's corporate sustainability ranking and GRI sustainability reporting in the European stock markets. Business Ethics: A European Review, 25(1), 1-25. https://doi.org/10.1111/beer.12079

Kothari, S. P. (2001). Capital markets research in accounting. Journal of Accounting and Economics, 31(1), 105-231. https://doi.org/10.1016/S0165-4101(01)00030-1

Kothari, S. P., \& Zimmerman, J. (1995). Price and return models, Journal of Accounting and Economics, 20(2), 155-192. https://doi.org/10.1016/0165-4101(95)00399-4

Lee, K.W., \& Yeo, G. (2016). The association between integrated reporting and firm valuation. Review of Quantitative Finance \& Accounting, 47(4), 1221-1250. https://dx.doi.org/10.1007/s11156-015-0536-y

Lev, B., \& Feng, G. (2016). The End of Accounting and the Path Forward for Investors and Managers. Hoboken, New Jersey: John Wiley \& Sons, Inc.

Loprevite, S., \& Ricca, B. (2016). La value relevance delle informazioni di bilancio sui crediti deteriorati: il caso delle banche italiane. Economia Aziendale Online, 7(3), 221-235. https://dx.doi.org/10.13132/2038-5498/7.3.221-235

Loprevite, S., Ricca, B., \& Rupo D. (2017). The Value Relevance of the Integrated Reports Under The Framework of IIRC: Empirical Evidence from a Sample of European Companies. Paper presented at 13th 
Interdisciplinary Workshop on Intangibles and Intellectual Capital. Value creation, Integrated reporting and Governance, Ancona, Italy, 21-22 September.

Lourenco, I. C., Callen, J. L., Branco, M. C., \& Curto, J. D. (2014). The value relevance of reputation for sustainability leadership. Journal Business Ethics, 119(1), 17-28. https://dx.doi.org/10.1007/s10551-012-1617-7

Mechelli, A. (2013). La Value Relevance del bilancio di esercizio. Modelli, metodologie di ricerca ed evidenze empiriche. Turin: Giappichelli editore.

Middleton, A. (2015). Value relevance of firms' integral environmental performance: evidence from Russia. Journal of Accounting and Public Policy, 34(2), 204-211. https://doi.org/10.1016/j.jaccpubpol.2014.12.001

Morros, J. (2016). The integrated reporting: A presentation of the current state of art and aspects of integrated reporting that need further development. Intangible Capital, 12(1), 336-356. http://dx.doi.org/10.3926/ic.700

Ohlson, J.A. (1995). Earnings, Book Values and Dividends in Equity Valuation. Contemporary Accounting Research, 11(2), 661-687. https://dx.doi.org/10.1111/j.1911-3846.1995.tb00461.x

Pope, P. F., \& McLeay, S. J. (2011). The European IFRS experiment: Objectives, research challenges and some early evidence. Accounting and Business Research, 41(3), 233-266. https://doi.org/10.1080/00014788.2011.575002

Qiu, Y., Shaukat, A., \& Tharyan, R. (2014). Environmental and social disclosures: link with corporate financial performance. British Accounting Review, 48(1), 102-116. http://dx.doi.org/10.1016/j.bar.2014.10.007

Schadewitz, H. J., \& Niskala, M. (2010). Communication via responsibility reporting and its effect on firm value in Finland. Corporate Social Responsibility and Environmental Management, 17, 96-106. https://dx.doi.org/10.1002/csr234

Setia, N., Abhayawansa, S., Joshi, M., \& Huynh, A. V. (2015). Integrated reporting in South Africa: Some initial evidence. Sustainability Accounting, Management and Policy Journal, 6(3), 397-424. https://doi.org/10.1108/SAMPJ-03-2014-0018

Soderstrom, N. S., \& Sun, K. J. (2007). IFRS Adoption and Accounting Quality: A review. European Accounting Review, 16(4), 675-702. https://doi.org/10.1080/09638180701706732

Solomon, J., \& Maroun, W. (2012). Integrated Reporting: The Influence of King III on Social, Ethical and Environmental Reporting. London: The Association of Chartered Certified Accountants

Vafaei, A., Taylor, D., \& Ahmed, K. (2011). The value relevance of intellectual capital disclosures. Journal of Intellectual Capital, 12(3), 407-429. https://doi.org/10.1108/14691931111154715

Zambon, S. (2004). Intangibles and intellectual capital: an overview of the reporting issues and some measurement models. In P. Bianchi, \& S. Labory (Eds.), The Economic Importance of Intangible Assets (pp. 153-183). London: Ashgate.

\section{Notes}

Note 1. The Variance Inflation Factor (VIF) is the reciprocal of tolerance. The tolerance index is used to estimate how much a variable is correlated to others and indicates the quantity of variance of an independent variable that is not explained by others $T_{i}=\left(1-R_{i}{ }^{2}\right)$ where $R_{i}{ }^{2}$ is the coefficient of determination in the regression of the variable $i$ on the other independent variables.

Note 2. The hierarchy principle states that if we include an interaction in a model, we also have to include the main effects, even if the associated $p$ values are not significant. We decided to exclude the variable since its inclusion did not make the other variables significant. Its exclusion, on the other hand, allows us to obtain a more stable model. According to the principle of parsimony, in the absence of particular proof, it is preferable to use the simplest model.

Note 3. In this case $\mathrm{F}=((\mathrm{SQR}$ (model with interactions)-SQR (model without interactions) $\left./\left(\mathrm{gl}_{1}-\mathrm{gl}_{2}\right)\right) / \mathrm{MQE}$ (model with interactions); with $H 0: \beta_{4}=\beta_{5}=\beta_{6}=0$ (there is no interaction) and $H 1: \beta_{4}=\beta_{5}=\beta_{6} \neq 0$ (there is interaction) 


\section{Copyrights}

Copyright for this article is retained by the author(s), with first publication rights granted to the journal.

This is an open-access article distributed under the terms and conditions of the Creative Commons Attribution license (http://creativecommons.org/licenses/by/4.0/). 